\title{
Response of some Maize Hybrids (Zea mays L.) to NPK Fertilization
}

\author{
H.A. Awadalla ${ }^{(1) \#}$, Gh.F.H. El-Sheref ${ }^{(1)}$ and A.M. Abd El-Hafeez ${ }^{(2)}$ \\ ${ }^{(1)}$ Soil, Water and Environment Research, Institute, Agricultural Research Center \\ (ARC), Giza, Egypt; (2)Department of Soil and Water, Faculty of Agriculture, Beni- \\ Suef University, Beni-Suef, Egypt.
}

\begin{abstract}
M ODES MAIZE hybrids need to high amounts of nitrogen, phosphorus and potassium; therefore, two field experiments were conducted at the Experimental Farm of Sids Agricultural Research Station, ARC, Beni-Suef Governorate, Egypt during the two successive seasons of 2015 and 2016 to evaluate the effect of three NPK levels, i.e., 80/6/10, 120/12/20 and $140 / 18 / 30 \mathrm{~kg} \mathrm{~N}, \mathrm{P}_{2} \mathrm{O}_{5}$ and $\mathrm{K}_{2} \mathrm{O} /$ fad , respectively under four maize hybrids, namely, white single cross 10 , white three way cross 128 , yellow single cross 168 and yellow three way cross 368 . Results showed that white single cross 10 gave the highest values of maize growth, yield and yield components as well as NPK uptake in grains and/or stover, except 100 grain weight and NPK concentration in grains and stover which were not affected. On the other hand, yellow three way cross 368 possessed the lowest values. The highest dose of NPK fertilizers produced the highest growth traits, yield and yield components and NPK uptake. The number of rows/ear, number of grains/row and NPK concentration in grains and stover. The white single cross 10 when supplied with $140 / 18 / 30 \mathrm{~kg} \mathrm{~N}, \mathrm{P}_{2} \mathrm{O}_{5}$ and $\mathrm{K}_{2} \mathrm{O} /$ fad produced the highest values of growth, yield and yield components traits. The lowest values were exerted under yellow three way cross 368 when received $80 / 6 / 10 \mathrm{~kg} \mathrm{~N}, \mathrm{P}_{2} \mathrm{O}_{5}$ and $\mathrm{K}_{2} \mathrm{O} /$ fad, respectively
\end{abstract}

Keywords: Maize hybrids, NPK fertilizers, Growth, Yield and its components and nutrient status.

\section{Introduction}

Maize (Zea mays L.) is one of the most widely grown cereals in the world. It is the third important staple food crop both in terms of area and production after wheat and rice in Egypt. There is a wide gap, between the ever growing increase of consumption and local production, yet this could be narrowed through the use of high yielding hybrids and optimizing cultural practices, especially mineral NPK fertilization. Many authers reported that maize hybrids differed in productivity and its response to nutrient applications, such as Sharifi \& Taghizadeh (2009) and Faheed et al (2016). Single cross 10 hybrid surpassed three way cross 310 in plant height, number of green leaves/plant and ear leaf area (Moharram, 2011). There are differential response of maize hybrids regarding to leaf area index, leaf area duration, net assimilation rate and crop growth rate (Luque et al., 2006 and Azadgoleh \& Kazmi, 2007). Maize hybrids differed in their grain and stover yields (Ahmed, 2011). In this connection, Kandil (2013) reported that single cross 10 exhibited the maximum values of all growth and yield and its components comparing with three ways cross 329 , Single cross 122 , Single cross 129.

Nitrogen fertilizer is the most important element for growth, yield and its components as well as grain quality. Nitrogen plays an essential rule in many compounds for plant growth, chlorophyll and many enzymes (Namakka et al., 2012). Application of $120 \mathrm{~kg} / \mathrm{fad}$ produced significant increases in number of leaves/plant, plant height and ear leaf area (Bamuaafa, 2012). Chemical status of maize grains are enhanced by nitrogen application (Ali et al., 1999). Shirazi et al. (2011) found that nitrogen application improved maize yield. Additionally, Badr \& Authman (2006), Kandil (2013) and Faheed et al. (2016) stated that increasing level of nitrogen fertilization led to increase growth and yield and its components of maize.

Phosphorus is an important limiting nutrient after nitrogen in majority of soils for crop production. It is supposed that phosphorus is effectively translocated into grain at high rates, since $\mathrm{P}$ is necessary for the production of protein, phospholipids and phytin (Trung \& Yoshida, 1982).

"Corresponding author email: hamedawadallaelaswany@yahoo.com

DOI: 10.21608/agro.2018.5737.1124

C2018 National Information and Documentation Center (NIDOC) 
It exerts many, varied functions in plant metabolism and hence inadequate phosphate supply to the plant seriously affects numerous metabolic processes. However, it appears that the most important function is its formation of pyrophosphate bonds allow energy transfer. Furthermore, the role of phosphorus in enhancing plant growth is due to its promoting root growth and extention where more soil surfaces are and hence more nutrients and water uptake are expected (Fagaria et al., 1997).

Potassium plays vital role as nitrogen and phosphorus in plant growth and crop production (Bukhsh et al., 2012). It plays a key role in activation of more than 60 enzymes (Tisdale et al., 1990). It maintains turgor pressure of cell and help in osmoregulation of cells, assists in opening and closing of stomata (Mengel \& Kirkby, 1987). It affects the transport of assimilates and regulates the rate of photosynthesis in plant. Its application enhanced plant growth and development. Maize hybrids respond to potassium application differently due to difference in its uptake, translocation, accumulation, growth and utilization (Nawaz et al., 2006 and Minjian et al., 2007).

The world wide experience shows that more than $50 \%$ of the increase in crop production yields is due to fertilizers (Braun \& Roy, 1983). On average, reports of FAO showed that one $\mathrm{kg}$ of nutrients $\left(\mathrm{N}+\mathrm{P}_{2} \mathrm{O}_{5}+\mathrm{K}_{2} \mathrm{O}\right)$ produces about ten $\mathrm{kg}$ cereal grain (FAO, 1981).

\section{Materials and Methods}

Two field experiments were conducted at the Experimental Farm of Agricultural Research Station, ARC, Beni-Suef Governorate, Egypt during the two successive seasons of 2015 and 2016, to evaluate the response of four maize hybrids, namely white single cross 10 (S.C.10), white three way cross 128 (T.W.128), yellow single cross 168 (S.C.168) and yellow three way cross 368 (T.W. 368) to NPK fertilization $(80 / 6 / 10$, $120 / 12 / 20$ and $140 / 18 / 30 \mathrm{~N}, \mathrm{P}_{2} \mathrm{O}_{5}, \mathrm{~K}_{2} \mathrm{O} \mathrm{kg} / \mathrm{fad}$ ), respectively. The experimental design was split plot in four replicates, where maize hybrids were laid out in the main plots while NPK fertilization in the sub-plot.

Nitrogen fertilizer added in the soil as urea $(46.5 \% \mathrm{~N})$ in two equal doses, the first at 30 and the second at 45 days after sowing. Phosphorus and potassium fertilizers were added as superphosphate $\left(15.5 \% \mathrm{P}_{2} \mathrm{O}_{5}\right)$ and potassium sulphate $\left(48 \% \mathrm{~K}_{2} \mathrm{O}\right)$, respectively before planting.

Soil samples $(0-30 \mathrm{~cm})$ were collected before planting from the experimental sites in the two seasons to determine some physical and chemical properties according to Klute (1982) and Page et al. (1982), respectively and listed in Table 1.

TABLE 1. Some physical and chemical properties of the experimental soil.

\begin{tabular}{|c|c|c|}
\hline Properties & $\begin{array}{c}\text { First } \\
\text { season }\end{array}$ & $\begin{array}{l}\text { Second } \\
\text { season }\end{array}$ \\
\hline \multicolumn{3}{|l|}{ Particle size distribution } \\
\hline Sand \% & 20.83 & 15.80 \\
\hline Silt \% & 25.16 & 29.17 \\
\hline Clay $\%$ & 54.01 & 55.03 \\
\hline Texture grade & Clay & Clay \\
\hline $\begin{array}{l}\mathrm{pH} \text { (in 1:2.5 soil- water } \\
\text { suspension) }\end{array}$ & 7.92 & 8.00 \\
\hline $\begin{array}{l}\mathrm{EC}, \mathrm{dSm}^{-1} \text { (in } 1: 5 \text { soil-water } \\
\text { extraction) }\end{array}$ & 1.28 & 1.37 \\
\hline Available N ( $\left.\mathrm{mg} \mathrm{kg}^{-1}\right)$ & 22.3 & 21.8 \\
\hline Available P $\left(\mathrm{mg} \mathrm{kg}^{-1}\right)$ & 8.9 & 9.2 \\
\hline Available K $\left(\mathrm{mg} \mathrm{kg}^{-1}\right)$ & 178 & 185 \\
\hline
\end{tabular}

The plot area was $3 \times 3.5 \mathrm{~m}=1 / 400 \mathrm{fad}$. Each experimental plot consisted of five rows, three meters along and $0.70 \mathrm{~m}$ apart. Grains of the studied maize hybrids were sowing in hills, $0.30 \mathrm{~m}$ apart in 15 and 19 May in both seasons, respectively. Thinning was done before first irrigation to one plant/hill. Other cultural practices for maize production were done as in district.

Five plants were randomly taken from each plot during tasseling- silking stage (about 60 days from sowing) from the two inner rows to measure the growth parameters as, plant height $(\mathrm{cm})$ and dry weight/plant (g).

At harvesting, five plants were randomly taken from each plot from the two inner rows to measure some yield components, i.e., number of rows/ear, number of grains/row and 100 grain weight $(\mathrm{g})$.

Also, grain and stover yields were measured for each plot and calculated as ardab and ton/fad, respectively. Nitrogen, phosphorus and potassium concentrations were determined in grains and stover according to the method described by A.O.A.C (1975), then N, P and K uptake by grains and/or Stover $\left(\mathrm{kg} \mathrm{fad}^{-1}\right)$ were calculated. 
All data were subjected to the proper statistical analysis according to methods of Snedecor \& Cochran (1980). Treatment means were compared by L.S.D test at 0.05

\section{Results and Discussion}

Growth, yield and yield components

Data in Table 2 represent the response of growth, yield and yield components of some maize hybrids to NPK fertilization. Maize hybrids expressed significant differences, where white S.C.10 gave the tallest plant and heaviest dry matter/plant. Followed by yellow S.C.168. However, yellow T.W.C.368 produced the lowest values of both plant height and dry weight. Concerning yield components, the results clearly showed that number of rows/ear and number of grains/row were significantly affected by maize hybrids, while 100 grain weight was not affected. The maximum number of rows/ear and number of grains/row were recorded for white S.C.10, while yellow T.W.368 scored the lowest ones. With regard to grain and stover yields, the data showed that maize yield were significantly differed due to maize hybrids. Similarly white S.C.10 gave the highest grain and stover yields (22.55ardab/fad and 3.21ton/fad, respectively in the first season), whereas yellow T.W.388 produced the lowest grain and stover yields, 19.11 ardab/fad and 2.65ton/ fad, respectively in the first season. Same trends were obtained in the second season. In general, it noticed that single cross hybrids, whether white or yellow gave higher values of growth, yield and its component parameters comparing with white or yellow three way cross hybrids. In this connection, Epinal et al (2000) and Delibaltova et al. (2009) mentioned that the genetic potential of maize is markedly by hybrids, agro-ecological and climatic conditions as well as by the technology of growing. These results are in accordance with those obtained by Hokmalipour \& Darbandi (2011) and Kandil (2013).

Considering NPK fertilization, the data in Table 2 indicated that both plant height and dry weight/plant were significantly respond to NPK levels. The highest NPK level gave the tallest and heaviest maize plant. 140/18/30kg N, $\mathrm{P}_{2} \mathrm{O}_{5}$, $\mathrm{K}_{2} \mathrm{O} /$ fad increased plant height and dry weight/ plant by about 1.9 and $3.6 \%$ when compared with $80 / 6 / 10 \mathrm{~kg} \mathrm{~N}, \mathrm{P}_{2} \mathrm{O}_{5}, \mathrm{~K}_{2} \mathrm{O} /$ fad in the first season. Similar trends were obtained in the second season, For the yield components, results showed that, only 100 grain weight was significantly affected by NPK fertilization, while number of rows/ear and number of grains/row was not affected. The weight of maize grains increased as NPK levels increased in both seasons. The increment of maize growth and 100 grain weight due to increasing NPK levels is mainly explained that these nutrients which are the most important nutrients for plant growth and development, which needed to a large quantity (Mengel \& Kirby, 1987). These results are in line with those obtained by Gul et al. (2015) and Hassanien (2018). As for grain and stover yields, it is evident from data that the treatment of $140 / 18 / 30 \mathrm{~kg} \mathrm{~N}, \mathrm{P}_{2} \mathrm{O}_{5}, \mathrm{~K} 2 \mathrm{O} /$ fad gained the highest grain and stover yields in both seasons, while the treatment of $80 / 6 / 10 \mathrm{~kg} \mathrm{~N}, \mathrm{P}_{2} \mathrm{O}_{5}, \mathrm{~K}_{2} \mathrm{O} /$ fad gave the lowest ones. The effect of highest dose of NPK fertilizers surpassed the effect of the lowest dose on grain and stover yields by about 14.4 and $20.1 \%$, respectively in the first season. Similar trends were obtained in the second one. The positive effect of NPK fertilization on grain and stover yields is mainly due to its effect on growth parameters and 100 grain weight as the above mentioned discussed. These results are similar to those obtained by Memon et al. (2013) and Hassanien (2018).

With regard to the interaction effect between maize hybrids and NPK fertilization, the results clearly showed that all studied maize growth, yield and yield components traits were not significantly effected by this interaction factors.

\section{Nutrients status}

Nutrient status expressed as N, P and K concentrations and uptake in grains and stover as affected by maize hybrids and NPK fertilization were given in Tables 3, 4 and 5. Results in Table 3 clearly revealed that NPK concentrations in both grains and stover were not significant respond to maize hybrids. On the other hand, maize hybrids had a remarkable effect on $\mathrm{N}, \mathrm{P}$ and $\mathrm{K}$ uptake in grains and/or stover (Tables 4 and 5). It could be arranged the $\mathrm{N}, \mathrm{P}$ and $\mathrm{K}$ uptake in grains or stover as well as total uptake for the four studied hybrids in the following descending order: White single cross $10>$ yellow single cross $128>$ white three way cross $128>$ yellow three way cross 168 . The difference in nutrient uptake for maize hybrids may be due to their different genotypic which occupied larger surface area of contact between roots and soil surface, consequently increased nutrient uptake at the root-soil interface to mention a larger diffusive gradient towards roots (Bukhsh, 2010). 


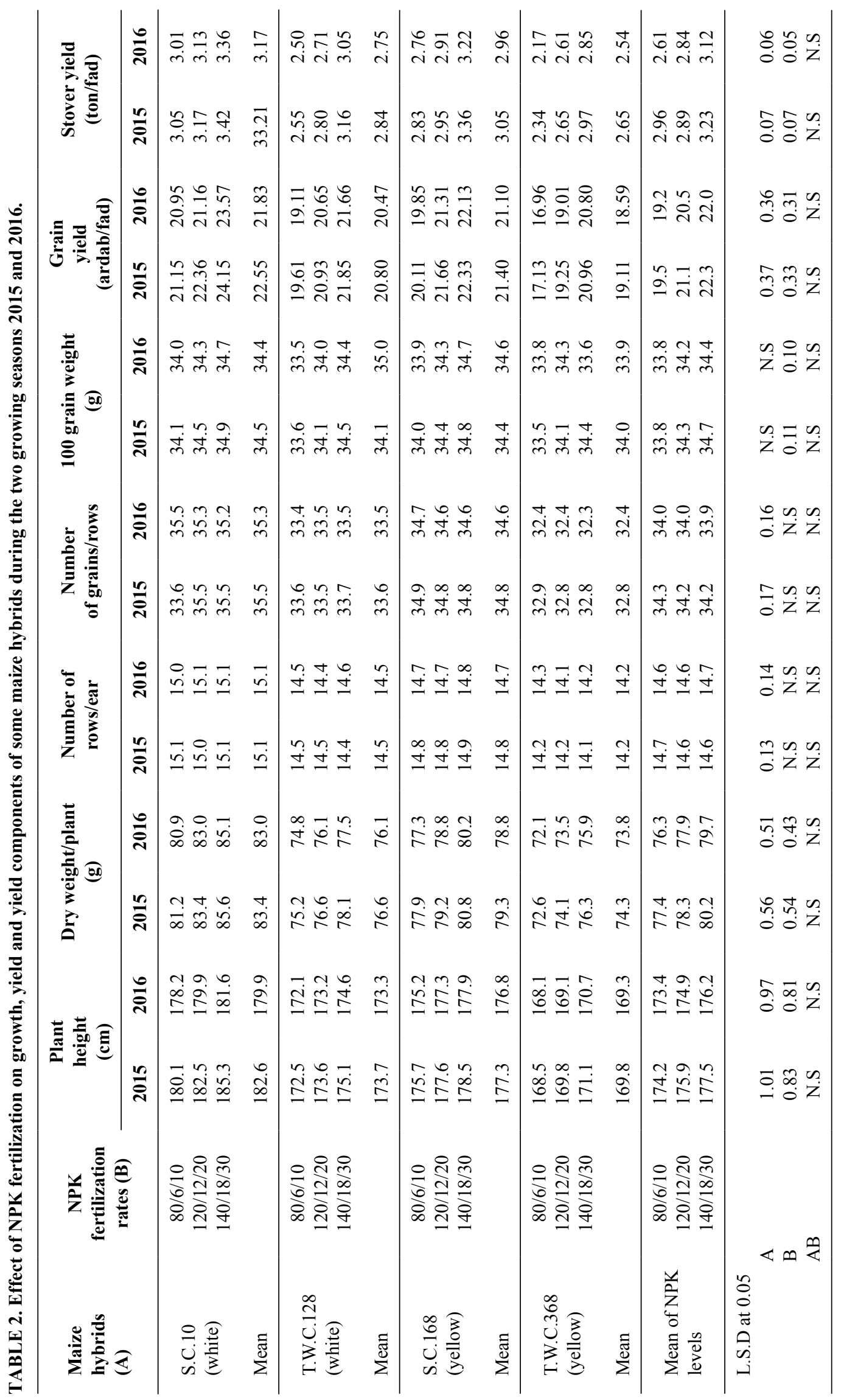

Egypt. J. Agron. Special Issue (2018) 


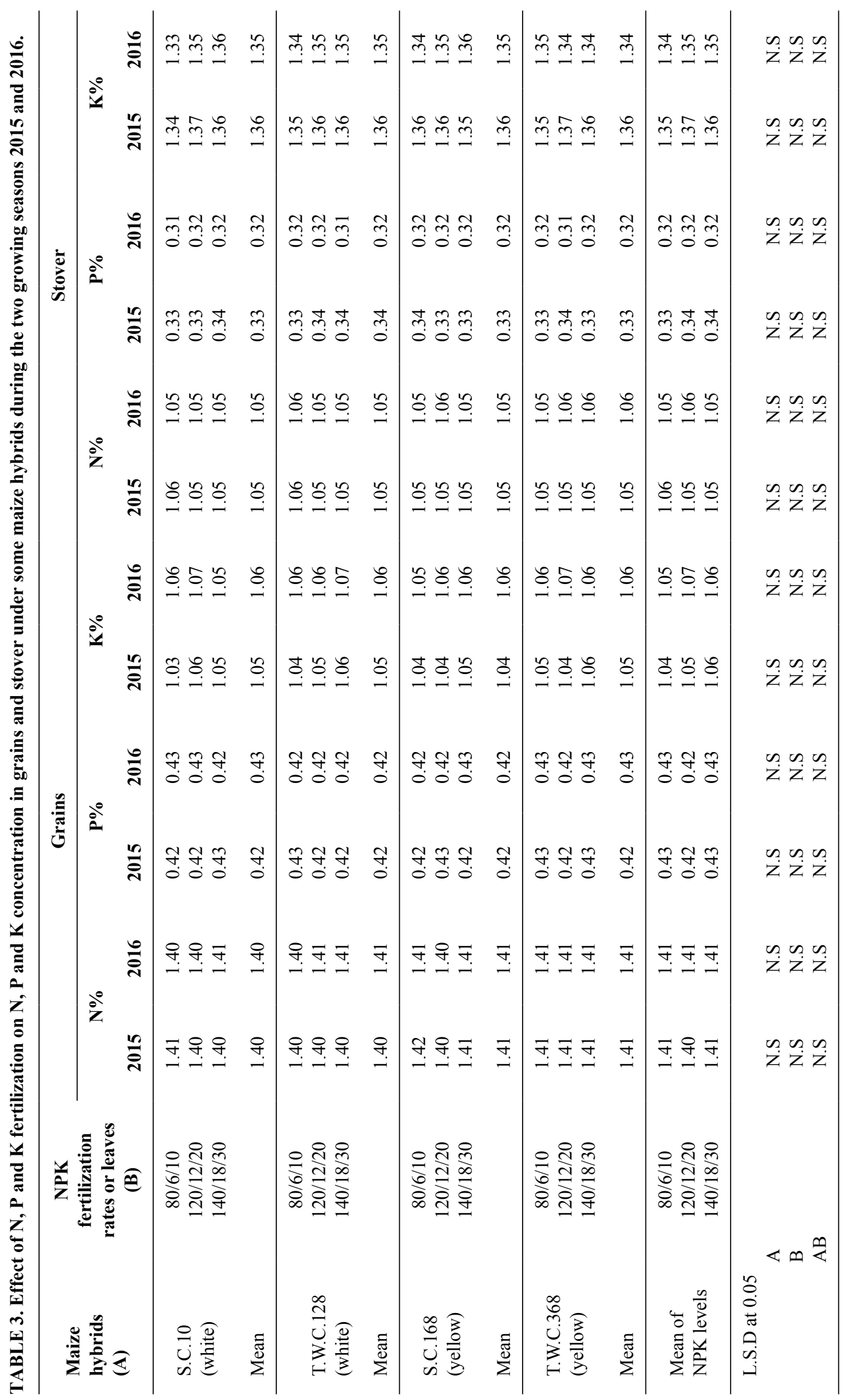






Egypt. J. Agron. Special Issue (2018) 
TABLE 5. Effect of N, P and $K$ fertilization on total N, P and $K$ uptake under some maize hybrids during the two growing seasons 2015 and 2016 .

\begin{tabular}{|c|c|c|c|c|c|c|c|}
\hline \multirow{2}{*}{$\begin{array}{l}\text { Maize hybrids } \\
\text { (A) }\end{array}$} & \multirow{2}{*}{$\begin{array}{c}\text { NPK fertilization } \\
\mathrm{N}, \mathrm{P}_{2} \mathrm{O}_{5}, \mathrm{~K}_{2} \mathrm{O} / \text { fad (B) }\end{array}$} & \multicolumn{2}{|c|}{$\mathrm{N}$ (kg/fad) } & \multicolumn{2}{|c|}{$P$ (kg/fad) } & \multicolumn{2}{|c|}{$\mathrm{K}(\mathrm{kg} / \mathrm{fad})$} \\
\hline & & 2015 & 2016 & 2015 & 2016 & 2015 & 2016 \\
\hline $\begin{array}{l}\text { S.C. } 10 \\
\text { (white) }\end{array}$ & $\begin{array}{c}80 / 6 / 10 \\
120 / 12 / 20 \\
140 / 18 / 30\end{array}$ & $\begin{array}{l}74.17 \\
77.10 \\
83.27\end{array}$ & $\begin{array}{l}72.65 \\
74.37 \\
81.84\end{array}$ & $\begin{array}{l}22.53 \\
23.65 \\
26.14\end{array}$ & $\begin{array}{l}21.92 \\
22.77 \\
24.64\end{array}$ & $\begin{array}{l}71.37 \\
76.60 \\
82.03\end{array}$ & $\begin{array}{l}71.10 \\
73.99 \\
80.33\end{array}$ \\
\hline Mean & & 78.18 & 76.29 & 24.11 & 23.11 & 76.67 & 75.14 \\
\hline $\begin{array}{l}\text { T.W.C. } 128 \\
\text { (white) }\end{array}$ & $\begin{array}{c}80 / 6 / 10 \\
120 / 12 / 20 \\
140 / 18 / 30\end{array}$ & $\begin{array}{l}65.43 \\
70.45 \\
76.05\end{array}$ & $\begin{array}{l}64.06 \\
69.26 \\
74.83\end{array}$ & $\begin{array}{l}20.20 \\
21.85 \\
23.56\end{array}$ & $\begin{array}{l}19.27 \\
20.83 \\
22.25\end{array}$ & $\begin{array}{l}62.96 \\
68.83 \\
75.44\end{array}$ & $\begin{array}{l}61.84 \\
67.26 \\
73.61\end{array}$ \\
\hline Mean & & 70.64 & 69.38 & 21.87 & 20.78 & 69.08 & 67.57 \\
\hline $\begin{array}{l}\text { S.C.168 } \\
\text { (yellow) }\end{array}$ & $\begin{array}{c}80 / 6 / 10 \\
120 / 12 / 20 \\
140 / 18 / 30\end{array}$ & $\begin{array}{l}69.73 \\
73.40 \\
79.31\end{array}$ & $\begin{array}{l}68.14 \\
72.65 \\
77.46\end{array}$ & $\begin{array}{l}21.41 \\
22.74 \\
24.20\end{array}$ & $\begin{array}{l}20.48 \\
21.87 \\
23.60\end{array}$ & $\begin{array}{l}67.79 \\
71.64 \\
78.16\end{array}$ & $\begin{array}{l}66.18 \\
70.96 \\
76.61\end{array}$ \\
\hline Mean & & 74.15 & 72.75 & 22.78 & 21.98 & 72.53 & 71.25 \\
\hline $\begin{array}{l}\text { T.W.C. } 368 \\
\text { (yellow) }\end{array}$ & $\begin{array}{c}80 / 6 / 10 \\
120 / 12 / 20 \\
140 / 18 / 30\end{array}$ & $\begin{array}{l}58.39 \\
65.86 \\
72.59\end{array}$ & $\begin{array}{l}56.27 \\
65.48 \\
71.29\end{array}$ & $\begin{array}{l}18.06 \\
20.36 \\
22.44\end{array}$ & $\begin{array}{l}17.13 \\
19.26 \\
22.25\end{array}$ & $\begin{array}{l}56.79 \\
64.34 \\
71.44\end{array}$ & $\begin{array}{l}52.44 \\
63.47 \\
69.09\end{array}$ \\
\hline Mean & & 65.61 & 64.35 & 20.29 & 19.55 & 64.19 & 61.67 \\
\hline Mean of NPK levels & $\begin{array}{c}80 / 6 / 10 \\
120 / 12 / 20 \\
140 / 18 / 30 \\
\end{array}$ & $\begin{array}{l}66.93 \\
71.70 \\
77.81 \\
\end{array}$ & $\begin{array}{l}65.28 \\
70.44 \\
76.36 \\
\end{array}$ & $\begin{array}{l}20.55 \\
22.15 \\
24.09 \\
\end{array}$ & $\begin{array}{l}19.70 \\
21.83 \\
23.19 \\
\end{array}$ & $\begin{array}{l}64.73 \\
70.35 \\
76.77 \\
\end{array}$ & $\begin{array}{l}62.89 \\
68.92 \\
74.91 \\
\end{array}$ \\
\hline $\begin{aligned} & \text { L.S.D at } 0.05 \\
& \mathrm{~A} \\
& \mathrm{~B} \\
& \mathrm{AB}\end{aligned}$ & & $\begin{array}{l}1.17 \\
1.13 \\
\text { N.S }\end{array}$ & $\begin{array}{l}1.13 \\
1.07 \\
\text { N.S }\end{array}$ & $\begin{array}{l}0.75 \\
0.67 \\
\text { N.S }\end{array}$ & $\begin{array}{l}0.79 \\
0.71 \\
\text { N.S }\end{array}$ & $\begin{array}{l}1.12 \\
1.10 \\
\text { N.S }\end{array}$ & $\begin{array}{l}1.06 \\
1.00 \\
\text { N.S }\end{array}$ \\
\hline
\end{tabular}

Similar results were obtained by Rengel \& Damon (2008) and Ahmed et al. (2012).

Concerning the effect of NPK fertilization, data revealed that NPK concentrations in grains or stover was not respond to NPK levels which mainly due to the dilution effect, since increasing NPK levels increased grain and stover yields. However, NPK uptake in grains and/or stover were significantly increased as NPK dose increased. The total N, P, K caused by the high dose $(140 / 18 / 30 \mathrm{~kg}$ $\mathrm{N}, \mathrm{P}_{2} \mathrm{O}_{5}, \mathrm{~K}_{2} \mathrm{O} / \mathrm{fad}$, respectively) surpassed that due to the low dose $\left(80 / 6 / 10 \mathrm{~kg} \mathrm{~N}, \mathrm{P}_{2} \mathrm{O}_{5}, \mathrm{~K}_{2} \mathrm{O} /\right.$ fad, respectively) by about $16.3,17.2$ and $18.6 \%$, respectively in the first season. Similar trends were obtained in the second season. The positive effect of increasing NPK fertilization on NPK uptake is mainly explained by the effect of NPK fertilizers on grain and stover yields as mentioned before in Table 2, where nutrient uptake was calculated by multiplying grains and stover yield by nutrient concentration (Ismail et al., 2006). These results are in accordance with those obtained by Baldotto et al. (2012) and Hassanien (2018).
Results of the interaction between maize hybrids and NPK levels, clearly showed that N, $\mathrm{P}$ and $\mathrm{K}$ concentration or uptake did not respond to the interaction between these two studied factors. In general, the highest values of N, P and $\mathrm{K}$ uptake in grains and/or stover were recorded for white single cross 10 hybrids when fertilized with $140 / 18 / 30 \mathrm{~kg} \mathrm{~N}, \mathrm{P}_{2} \mathrm{O}_{5}, \mathrm{~K}_{2} \mathrm{O} /$ fad, respectively, while yellow Three way cross 168 hybrids when received $80 / 6 / 10 \mathrm{~kg} \mathrm{~N}, \mathrm{P}_{2} \mathrm{O}_{5}, \mathrm{~K}_{2} \mathrm{O} /$ fad, respectively exhibited the lowest ones.

\section{Conclusion}

The present study showed that growing white single cross 10 fertilized with $140 \mathrm{~kg} \mathrm{~N}+18 \mathrm{~kg}$ $\mathrm{P}_{2} \mathrm{O}_{5}+30 \mathrm{~kg} \mathrm{~K} / \mathrm{O} /$ fad recommended to get the maximum growth parameters, yield and yield components and N, P and $\mathrm{K}$ uptake in grains and/ or stover.

\section{References}

Ahmed, H.E.A. (2011) Effect of spatial distribution of plant under different watering regimes on the yield 
and its components of corn (Zea mays L.). M.Sc. Thesis, Agron. Dept., Fac. Agric., Assiut Univ., Egypt.

Ahmed, M., Bukhsh, A., Ahmed, R., Ali, A., Ishaque, M. and Rehman, A. (2012) Potassium use efficiency of maize hybrids. J. of Animal and Plant Sci. 22(3), 728-732.

Ali, A., Malik, A., Choudhry, M.A., Khaliq, M. and Rafique, M. (1999) Effect of doses of nitrogen on the growth, yield and protein content of two maize genotypes. Pak. J. Biol. Sci. 2(3), 889-89.

A.O.A.C. (1975) "Official Methods of Analysis", Association Official Analytical Chemists. $10^{\text {th }}$ ed., Washington, D. C., USA.

Azadgoleh, M.A.E. and Kazmi, Z. (2007) A study of the planting pattern anddensity effect on yield and physiological growth parameters in two corn cultivars. Ecology, Environ. and Conserv. 13(3), 467-472.

Badr, M.M. and Authman, Sanaa A. (2006) Effect of plant density, organicmanure, bio and mineral nitrogen fertilizers on maize growth and yield and soil fertility. Ann. Agri. Sci., Moshtohor, 44(1), 75-88.

Baldotto, M.A., Baldotto, L.E.B., Santana, R.B. and Marciano, C.R. (2012) Initial performance of maize in response to NPK fertilization combined with Herbaspirillum. Revista Cers, 95(6), 841-849.

Bamuaafa, M.S.S. (2012) Effect of irrigation and nitrogen fertilization on yield andquality of corn. Ph.D. Thesis, Agron. Depart., Fac. Agric., Assiut Univ., Egypt.

Braun, H. and Roy, R.N. (1983) Rational plant nutrition and fertilizer use forincreased crop production. $7^{\text {th }}$ Session of the Regional Commission on Land and Water use in the Near East, 16-18 March, FAO, Rome, Italy.

Bukhsh, M.A.A.H.A. (2010) Production potential of three maize hybrids as influenced by varying plant density and potassium application. Ph.D. Thesis, Depart. Agron., Univ. Agric., Faisalabad.

Bukhsh, M.A.A.H.A., Ahmad, R., Iqbal, J., Maqbool, M.M., Ali, A., Ishaque, M. and Hussain, S. (2012) Nutritional and physiological significance of potassium application in maize hybride crop production. Pakistan J. Nutri. 11, 187-202.
Delibaltova, V., Toney, T. and Zheliazkov, I. (2009) Effect of sowing density on the productivity of maize hybrids cultivated for grain under irrigation in Plovdiv region. Plant Sci. 46, 412-416.

Epinal, C., Dousse, S., Lorgeon, J., Denis, J., Bonhomme, R., Carolo, P. and Charosset, A. (2000) Interpretation of genotype and environment interactionsfor early maize hybrids over 12 years. Crop Sci. 41, 663-669.

Fagaria, N.K., Baligar, V.C. and Jones, C.A. (1997) "Growth and Mineral Nutrition of Field Crops". Marcel, Dekker, Inc., New York.

Faheed-Fayza, A., Mohamed, E.I. and Mahmoud, H.M. (2016) Improvement ofmaize crop yield (Zea mays L.) by using of nitrogen fertilization and foliar spray of some activators. J. Eco. Heal. Environ. 4 (1), 33-47.

F.A.O. (1981) Crop production levels of fertilizer use FAO. Fertilizer and PlantNutr. Bull. 2. FAO. Rome, Italy.

Gul, S., Khan, M.H., Khanday, B.A. and Nabi, S. (2015) Effect of sowing methods and NPK levels on growth and yield of rainfad maize (Zea mays L.), Volume 2015, Article ID 198575, 6 pages. http:// dx.doi.org/10.1155/2015/198575

Hassanien, A.M.M. (2018) Studies on methods of NPK application for maize plant. Ph.D. Thesis, Fac. Agric., Moshtohor, Benha Univ., Egypt.

Hokmalipour, S. and Darbandi, M.H. (2011) Physiological growth indices in corn (Zea mays L.) cultivars as affected by nitrogen fertilizer levels. World Appl. Sci. J. 15(12), 1800-1805.

Ismail, S.A., Morsy, M.A., Omran, A.A. and Foaad, M.M. (2006) The productivity of some hybrids (Zea mays L.) grown in an alluvial soil under different nitrogen sources and levels. The Second Conf. on Farm Integra. Pest Manag., Fac. Agric., Fayuim Univ., 16-18 January.

Kandil, E.E.E. (2013) Response of some maize hybrids (Zea mays L.) to different levels of nitrogenous fertilization. J. Appl. Sci. Res. 9(3), 1902-1908.

Klute, A. (1982) "Methods of Analysis. Part-1: Physical and Mineralogical Methods", $2^{\text {nd }}$ ed. American Soc. of Agron., Madison, Wisconsin, USA. 
Luque, S.F., Cirilo, A.G. and Otegui, M.E. (2006) Genetic grains in grain yield and related physiological attributes in argentine maize hybrids. Field Crops Res. 95, 383-397.

Memon, S.Q., Miriat, M.S., Mughal, A.Q., Amjad, N., Saeed, M.A., Kalwar, S., Mirani, A.A. and Javed, H.I. (2013) Tillage and NPK effect on growth and yield of spring maize in Islamabad Pakistan. Paki. J. Res. 26(10), 32-39.

Mengel, K. and Kirby, E.A. (1987) "Principles of Plant Nutrition", $4^{\text {th }}$ ed., Inter. Potash Instit., Horgen, Switzerland.

Minjian, C., Haiqui, Y., Hongkui, Y. and Chungi, J. (2007) Difference in tolerance to potassium deficiency between maize inbred lines. Plant Prod. Sci. 10(1), 42-46.

Moharram, Z.A.M. (2011) Physiological response of corn hybrids to somecultural practices. M.Sc. Thesis, Agron. Depart., Fac. Agric., Assiut Univ., Egypt.

Namakka, A., Abubakar, I.U., Dadari, S.A., Ado, S.G., Hamid, A.H., Sharifai, A., Kura, H.N., Babaji, B.A. and Halliru, I. (2012) Effect of tillage system and nitrogenlevel on growth of maize (Zea mays L.) in Northern Guinea zone of Nigeria. Greener J. Agric. Sci. ISSN: 2276-7770, 2(5), 172-179.

Nawaz, L., Hassan, Z.U., Ranjha, A.M. and Arshad, M. (2006) Exploiting genotypic variation among fifteen maize genotypes of Pakistan for potassium uptake and use efficiency in solution culture. Pak. J. Bot. 38, 1689-1696.
Page, A.L., Miller, R.H. and Keeny, D.R. (1982) "Methods of Soil Analysis. Part II. Chemical and Microbiological Properties", $2^{\text {nd }}$ ed. Amer. Soc. Agron. Inc. Soil Sci. Sco. Amer. Inc. Madison, Wisconsin, USA.

Rengel, Z. and Damon, P.M. (2008) Crops and genotypes differ in efficiency of potassium uptake and use. Physiol. Plant, 10, 1399-3054.

Sharifi, R.S. and Taghizadeh, R. (2009) Response of maize (Zea mays L.) cultivars todifferent levels of nitrogen fertilizer. J. Food, Agri. Environ. 7(3-4), 518-521.

Shirazi, S.M., Sholichin, M., Jameel, M., Akib, S. and Azizi, M. (2011) Effect ofdifferent irrigation regimes and nitrogenous fertilizer on yield and growth parameters of maize. Inter. J. Physic. Sci. 6(4), 677-683.

Snedecor, G.W. and Cochran, W.G. (1980) "Statistical Methods", $7^{\text {th }}$ ed. Iowa State Univ. Press, Ames, Iowa, U.S.A.

Tisdale, S.L., Nelson, W.L. and Beaton, J.D. (1985) "Soil Fertility and Fertilizers". $4^{\text {th }}$ ed, Macmillan Publishing Company, New York, U.S.A.

Trung, B.C. and Yoshida, S. (1982) Nutrients uptake and its distribution patterns inmungbean. Japan. J. Trop. Agri. 26(3), 121-129.

(Received 18/10/2018) accepted 15/12/2018) 


\section{أستجابة بعض هجن الذرة الثامية للتسميد النيتروجيني الفوسفاتي البوتاسي \\ حامد علي عوض الله(1)، غادة فتح الله حافظ الشريف(1) و أحمد محمد عبدالحفيظ(2)

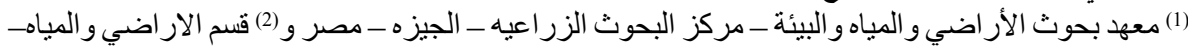

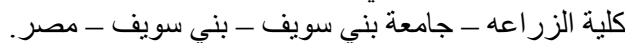

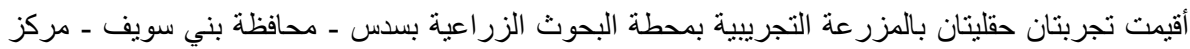

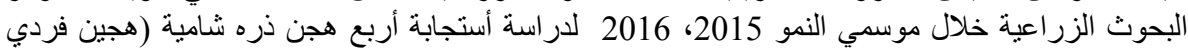

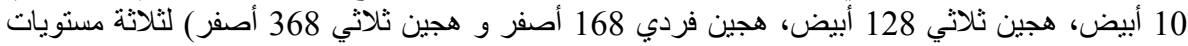
من التسميد النيتروجيني والفوسفاتي و البوتاسي (80/6/10، 120/12/20، الترتيب). وكانت أهم النتائج المتحصل عليها هي:

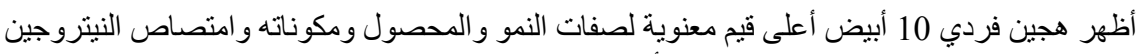

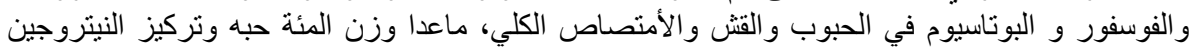


قيمه من بين تلك القيه.

أدى زيادة التسميد النيتروجيني و الفوسفاتي والبوتاسي إلى زياده معنوية في صفات النمو، المحصول

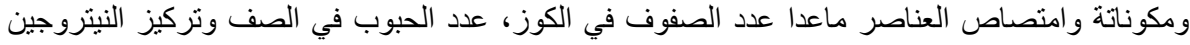
والفوسفور والبوتاسيوم في الحبوب و القش.



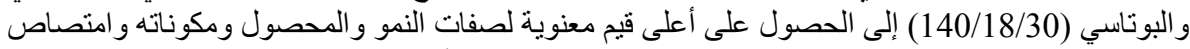

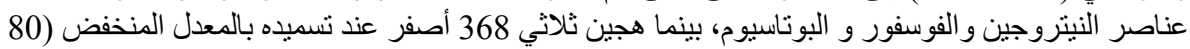

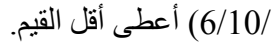

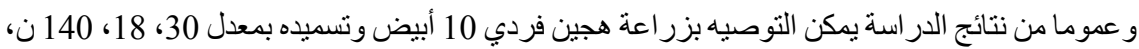
فو ا ، ، بو / / فدان على الترتيب للحصول على أعلى انتاجيه للأرة الثامية تحت ظروف منطقة مصر الوسطي. 